\title{
From Western Regions to Asia: On the Geographical Concept of "Silk Road" from the Perspective of Eastern and Western Civilizations
}

\author{
LI A-hui \\ Institute for the Global History of Civilizations, Shanghai International Studies University, China
}

Received: June 28, 2021

Accepted: July 23, 2021

Published: November 30, 2021

To cite this article: LI A-hui. (2021). From Western Regions to Asia: On the Geographical Concept of "Silk Road" from the Perspective of Eastern and Western Civilizations. Asia-Pacific Journal of Humanities and Social Sciences, 01: 3, 057-065, DOI: $\underline{10.53789 / \text { j.1653-0465.2021.0103.006 }}$

To link to this article: https: //doi.org/10.53789/ j.1653-0465.2021.0103.006

\begin{abstract}
Through the two geographical perspectives of Western Regions and Asia, we can understand the Silk Road in the historical context of comparing ancient Eastern and Western civilizations to more comprehensively investigate the formation history of the geographical concept of the Silk Road. The Western Regions reflect ancient China's cognition of Western civilization, while Asia is the observation and imagination of ancient Mediterranean civilization to the eastern world. In history, the scope of the Western Regions and Asia gradually expanded to outer space, and the extension of the two perspectives was almost synchronous, forming the civilization picture of the Western Regions and Asia in a broad sense. Therefore, the ancient Silk Road is not only the western region road from the east to the west but also the Asia road from the west to the east. The concept of the Silk Road in the modern sense is based on the integration of eastern and western geographical concepts after the 19th century, which also reflects the intersection of Western Regions and Asia.
\end{abstract}

Keywords: Western Regions; Asia; Silk Road; civilization view; geopolitical order

Notes on the contributor: LI A-hui holds a doctorate in philosophy, and he is a postdoctoral fellow at Shanghai International Studies University. His academic interest lies in historical philology.

\section{從“西域”圖景到“亞細亞” 論東西文明視域下的“絲綢之路”地理觀}

\author{
李阿慧
}

上海外國語大學

摘 要: 通過“西域”與“亞細亞”兩種觀察視角, 立足於古代東西文明比較的歷史境遇, 可以更加全面地理解“絲綢 
之路”地理觀念的形成史。“西域”體現了古代中國對西方世界的認知圖景, 而“亞細亞”是古代地中海文明對東方 世界的觀察與想像。在歷史上, “西域”與“亞細亞”的邊界逐漸向外部空間擴展, 兩種視角的外拓幾乎同步, 形成 了廣義西域與廣義亞洲的地理觀念, 這意味著古代“絲綢之路” 既是由東方通往西方的“西域”之路, 也是從西方朝 向東方的“亞細亞”之路。最後, 19 世紀之後“西域”與“亞細亞”兩種視域的融合, 也開啟了近代 “絲綢之路”文明 圖景的建構。

關鍵词: 西域; 亞洲; 絲綢之路; 文明交流; 地緣秩序

\section{引言}

晚近學術界對“絲絧之路”地理觀念的研究,一方面注重歐洲地理學家尤其是李希霍芬 (Richthofen Ferdinand von) 對 “絲綢之路” 概念的定義以及傳播, 並將其看作是近代亞洲地理觀念以及中心交通概念, 此 視角著眼於 “絲綢之路” 地理觀所蘊含的近現代歷史、文化以及經濟等領域的意義; 另一方面,學者也提出有 必要將“西域”等地理空間引入 “絲綢之路”研究,形成有新地方性與本土化的“絲路” 話語 ${ }^{1}$,這一研究視角 是從中國傳統的歷史地理觀念開拓對“絲綢之路”的認知視野。基於以往的研究視角,本文聚焦於“西域” 與 “亞細亞”雙重視角對“絲綢之路”的形成史進行研究,這實際上將“絲綢之路” 置於古代東西方文明比較的 歷史境遇之中加以理解,從而揭示其所蘊含的“世界歷史”敘述。

“西域”體現了古代中國對西方文明的認知圖景, 而 “亞細亞” 是古代地中海文明對東方世界的觀察與想 像,兩種視角之間既在地理隔絕中彼此相對, 又在歷史演進中相互交融。西元前 2 世紀以降,伴隨著東西方 文明交往的日益加深,西域與亞細亞的邊界逐漸向外部空間擴展,在其後的 1600 餘年中 (至 1500 年的地理 大發現時期) 兩種視角的外拓幾乎同步,形成了廣義西域與廣義亞洲的世界圖景。古代 “絲綢之路” 既是由 東方通往西方的“西域”之路,也是從西方朝向東方的“亞細亞”之路,它的形成與變遷是雙向度而最終得以 相互融合。近代以降,隨著西方地理觀在中國知識界的支配性地位, 學人開始全面接受 “亞洲” 地理觀, 在這 種情形之下,晚清學者開啟了對於西域與亞細亞兩種視域的融合與交匯,並最終確立了近代意義上的“絲絧 之路”文明圖景。

\section{一、廣義西域的天下圖景:古代中國的“絲綢之路”}

天下圖景作為一種古代中國的世界觀念, 是由華夏與四裔諸要素所組成的。華夏作為天下文明的核心 區,而四裔是對華夏四周各民族的統稱,包括西北內陸的“西域”, 以及東南、西南沿海的“島夷”與“西南 夷”。西域的特殊性應該置於天下圖景的普適性之中加以思考,隨著西漢以後的中央王朝與西域地方政權 的深人交往,西域圖景呈現出不斷向西擴展的趨勢, 逐漸由西域內屬國擴展至中亞、西亞乃至羅馬帝國,形 成了“廣義西域” 的觀察視角,這可以看作是古代中國對歐亞內陸文明主體的認知, 同時也形成了古代中國 “絲綢之路”的文明圖景。

在先秦時期,通常以“西戎”指代西域。“西戎”強調的是西北地區的部族屬性,而“西域”更強調西北的 地理空間屬性。先秦典籍中有大量華夏與西戎關係的記載,這些史料可以反映夏商周時期的基本史實。華 夏大體相當於《禹貢》“九州” 的範圍,春秋以降, 華夏與西戎雖然長期處於緊張的對峙, 但又有處於彼此交織 的關係之中,從而在文明譜系上不能加以完全分離。故而在古代中國的天下觀念之中, 華夏與四裔之間既 有文明系統的差異性,但又具備基於血緣與地緣的共通性與一體性。

西漢武帝時(前 138 年), 張騫始通西域被稱為“鏊空”, 相當於古代中國對西方世界的“地理大發現”, 這 也標誌著古代中國“絲絧之路” 文明圖景的最初確立。據《史記 - 大宛列傳》記載,張騫所陳述的西域是以大 
宛 (帕米爾高原以西的費爾幹納盆地) 為中心, 並向四方各區域的文明延伸, “其北則康居, 西則大月氏, 西南 則大夏, 東北則烏孫, 東則扜鳁、於真” (2)。漢武帝時期, 在擊潰了河西地區的匈奴部落之後, 先後設立了河西 四郡,並對西域諸國採取羈縻政策,所謂羈縻就是籠絡之義。而這種對西域的羈縻政策實際上也是為了抗 衡匈奴, 是漢帝國在國際範圍的合縱連横。因而,最早的西域圖景包含中央王朝對異域文明的“聯合”與“抗 衡” 兩方面因素, 並將華夏為中心的禮儀規範與價值體系向亞洲內陸擴散, 構成了天下圖景的週邊與邊界。

西漢以後中央王朝的“大一統” 觀念與天下圖景相適應, 王朝的統治不局限在設立郡縣的內地, 還進一 步滲人西域各地方政權, 從而也奠定了 “大中國” 的地理空間格局。《漢書 - 西域傳》對西域三十六國的分佈 有詳細記載: “在匈奴之西, 烏孫之南。南北有大山, 中央有河, 東西六千餘裏, 南北千餘裏。東則接漢, 阨以 玉門、陽關, 西則限以葱嶺。其南山, 東出金城, 與漢南山屬焉。其河有兩原: 一出葱嶺, 一出於閴。於闐在 南山下, 其河北流, 與葱嶺河合, 東注蒲昌海” ${ }^{3}$ 。大體相當於在天山與昆侖山之間的環塔克拉瑪幹沙漠的綠 洲地帶, 而且都是定居的城郭國,與匈奴、烏孫等逐水草而居的習俗不同。《漢書》輯錄了葱嶺以西的大宛、 安息、康居、條支等國,並對西域各國與長安的距離有非常精確的測量, 這反映了當時對西域的地理有較為 客觀的認知。而西域都護府的設置為漢王朝管轄西域地區提供了便利。因而, 西漢時期的陸上 “絲綢之路” 不僅僅可以看作長安至西域各綠洲王國之間的交通路線,也包含了政治與文化上的雙重聯繫。

但在東漢時期, 中原與西域的聯絡曾一度中斷,西域各地方政權也往往受到匈奴的控制。漢和帝時期 (91 年), 班超被任命為西域都護, 其後西域的五十餘國先後成為內屬國, 東西方文明交往的通道更加順暢, “其條支、安息諸國至於海瀕四萬裏外, 皆重譯貢獻” (4) 條支也即塞琉古朝敘利亞王國 ${ }^{5}$, 條支當時已經被 安息 (帕提亞帝國) 所吞併, 而成為其附屬蕃國, 但《後漢書》仍沿用條支的地理名稱, 因而西域的西端已經到 達伊朗高原西部至地中海的東岸。永元九年( 97 年), 班超派甘英出使大秦(羅馬帝國), 但僅抵達安息西部 的海濱就返回。值得注意的是, 《後漢書 - 西域傳》極為詳細地羅列了羅馬帝國的地理範圍、城邑數量、政治 制度、風俗習慣, 並記載了 166 年羅馬皇帝遣派使者到達中國的史跡, “其王常欲通使於漢, 而安息欲以漢繒 彩與之交市, 故遮関不得自達。至桓帝延喜九年, 大秦王安敦遣使自日南徼外獻象牙、犀角、玳琩, 始乃一通 焉” @ “大秦王安敦”為 161 年至 180 年在位的羅馬帝國皇帝馬可 - 奧勒留, 其全名為馬爾克 - 奧列里烏斯 - 安東尼 - 奧古斯都 (Marcus Aurelius Antoninus Augustus), 當時羅馬帝國正與帕提亞帝國進行常年戰爭, 帕 提亞帝國佔領了亞美尼亞與美索不達米亞地區, 西域路徑不完全暢通, 於是派往漢朝的使者從南部邊疆穿 行經日南 (越南) 到達漢朝, 這一記載反映了漢王朝與羅馬帝國兩大文明之間的第一次使節溝通。《後漢書》 中記載大秦通過與安息、天竺的海上貿易, 另外《梁書》記載東漢末大秦商賈往往到達東南亞的扶南、日南、 交趾等地行商。這說明羅馬帝國到達中國的早期路線很有可能是一條經由亞洲南部海岸線的商業路線, 在 東漢末乃至三國時期, 羅馬帝國派出的使節大多從越南抵達中國。北魏建國之後, 西域諸國屡次遣派使者 來貢,北魏又於 437 年派遣董琬出使西域十六國,他將沿途所見所聞傳回北魏,進而將西域劃分為四域: “自 葱嶺以東, 流沙以西為一域; 葱嶺以西, 海曲以東為一域; 者舌以南, 月氏以北為一域; 兩海之間, 水澤以南為 一域。” 這種劃分擴充了對西域地理空間的認識, 北魏時期歐亞之間的大通道也比以往更加暢通, 從葱嶺以 西到羅馬帝國的歐亞大陸形成了商賈往來不斷的局面。因而, 這顯示了早期 “絲綢之路” 已兼具陸上與海洋 兩種貿易路線。

如前所述,西域與西戎分別指代地理空間與民族分佈而言, 在《新唐書 - 西域傳》與《舊唐書 - 西戎傳》 的内容是相通的, 都是對古代西方文明的代稱。《舊唐書》有專門的突厥傳與回紅傳, 而西戎傳中的民族不 僅包括黨項、高昌、吐谷渾、焉惹、龜茲、疏勒、於闐等傳統的西域王國,還包括天竺、康國、波斯、拂菻、大食等 中亞、南亞以及西亞王國。而且, 直至唐朝, 西域是中華、突厥、阿拉伯、印度等多元文明的交匯地, 同時外來 文化也通過西域影響唐朝, 西域各國商賈、流人遷徙往來於長安、洛陽等地, 導致西域與唐朝之間的華化與 胡化現象十分突顯。進言之, 廣義西域的 “絲綢之路” 是各種異質文明相互交融的地理空間載體, 隋唐之後, 中華文明也是在充分吸收域外文明的基礎上而不斷演化與更新。 
值得一提的是, 從北宋到明後期所繪製的古代舆地圖中,可以看到不管是 “九州”還是 “中國” 僅限於長 城以内, 並不包含漠北地區, 也幾乎不包括嘉峪關以西的西域。蒙古帝國的建立使得多元化的西域趨向一 體化, 元朝的 “華夷圖” 及“混一圖” 則顯示出跨區域的天下圖景, 因而不僅僅包括 “九州” 範圍, 還包含了華 夏以外的西域、吐蕃、天竺、鞋靼等。《元經世大典圖》顯示的西域範圍已經達到賽普勒斯及埃及, 這意味著 元代實際上已經對歐亞大陸有較為全面與客觀的認知, 中央王朝並不強調基於 “國界” 的疆域觀, 而是注重 採取 “柔遠” 與 “冊封” 等方式確立一種跨越國界的天下觀念。《明史》中既有外國傳又有西域傳, 將明朝東 部及東南地區的藩屬國、歐洲國家以及北方的鞋靼、瓦刺等列人外國傳, 而又將烏斯藏 (西藏)、西北回部及 藩屬國、西亞各國列人西域傳。明代出現的各種西域地圖呈現出新的視野,如嘉靖年間《西域土地人物圖》 的西域範圍包括了嘉峪關到歐亞交界的土耳其伊斯坦布爾 ${ }^{8}$ 。這種廣義西域的圖景影響了清以後的西域地 圖繪製。

清代乾隆二十年(1755 年), 清廷平定了位於西域核心區的厄魯特蒙古准噶爾部, 其後纂修的《西域圖 志》反映清朝強盛時期的西域觀, 體現中央王朝固有的天下圖景, 全圖沒有國界線, 與疆域範圍的邊緣標示 各大藩屬部族和鄰邦。從清中期官修西域輿圖來看, 西域的南北範圍是以印度與俄國為界, 東西兩端則是 從嘉峪關到撒馬爾罕, 主要包括中亞地區的哈薩克、布魯特、浩罕、安集延、那木幹、塔什干、布哈拉等地, 以 及愛烏罕、痕都斯坦、阿勒提等地區。清朝中央政權與西域外屬國所建立的宗藩關係一直持續到清末, 隨著 俄國在 19 世紀中後期對西域各汗國的實際控制, 對於晚清知識界而言, 西域不再是天下圖景中的邊緣地帶, 而漸漸成為近代世界體系中 “亞洲” 的一部分。這也意味對古代 “ 絲綢之路” 的再認識, 也需要在古代西方地 理學傳統尤其是“亞洲”地理觀念的形成中加以重新思考。

\section{二、“亞細亞”地理觀:地中海文明視域下的“絲綢之路”}

“亞細亞” ( Asia) 一詞的起源很早,一般認為是由腓尼基人提出來, 指愛琴海以東的日出之地。“腓尼基 人生活在東地中海與黎巴嫩山脈之間陝窄的走廊地帶, 每天望見太陽下落的餘睴撒在海面上。黎巴嫩山脈 的背後是亞述人的天地, 西元前 9 世紀腓尼基併人亞述帝國後, 亞述人的語言裏也開始使用這個詞, 並承襲 腓尼基人在地中海東部的方位觀。” ${ }^{9}$ 因而, “亞細亞” 體現了希臘對東方的觀察視角, 其區域包括小亞細亞半 島以及更遠兩河流域和伊朗高原, 相應的文明系統為亞述及波斯。而“歐羅巴” ( Ereb) 指的是愛琴海以西的 日落之地, 相應於歐洲大陸及其以西。在《漢書 - 西域傳》中也將條支以西的地區描述為 “日人之地”, 實際 上是歐洲與亞洲交通的樞紐地帶, 從條支乘水西行正是經過小亞細亞半島以南的地中海區域, 而這與是腓 尼基人對歐洲 “日落之地” 的觀察視野完全相同。可以說, 亞洲地理觀念的起源是與地中海這一自然地理分 界有關, 同時也體現了地中海文明圈對東方異域的地理空間想像。

亞洲觀念隨著歐洲地理觀念的發展而不斷拓展與演變, 總體上經歷了古希臘至羅馬帝國、中世紀至文 藝復興時期、歐洲地理大發現時期三個歷史階段。這種地理圖景的變革與東西方文明之間日益加深的互動 有直接關聯, 與廣義西域的形成機制相類似, 亞洲圖景也伴隨著歐洲對東方持續的關注而發生視域上的東 擴, 因而“亞細亞” 在歐洲歷史上是一個逐漸生成與拓展的地理概念, 並且構成了古代西方對 “絲絧之路” 的 文明敘述。

第一,古希臘時期及羅馬帝國時期擴展了對亞洲地理的認識,標誌著地中海文明圈“絲綢之路”地理觀 的初步形成。古希臘歷史學家希羅多德 (Herodotus) 將亞洲、歐洲及非洲看作是一片大陸, 並對大陸邊緣的 海洋有重新的認識, “他堅持認為南面存在一個連續不斷的、從印度洋到大西洋的海洋。……他是第一個將 亞洲和非洲界限從尼羅河改為蘇伊士地峽的人” 10。從希羅多德開始, 希臘學者建立了對亞洲的較為系統的 知識體系, 亞洲的東部邊界也由波斯最終達到印度河流域。隨著亞曆山大的東征, 亞洲中部的面貌更加清 晰化, “東征所得地理資料, 則在埃及之亞曆山大城自成一體系, 而以希臘為中心; 最值得主義者, 為地蓋阿 
爾古斯 (Dichaearchus) 說, 謂有東西相貫之大山脈, 使整個亞細亞大陸, 劃為南北二部” (1)。亞曆山大的東征 路線是沿著小亞細亞以及波斯南部到達印度河流域, 而東西大山脈可以看作是從黑海與里海間的高加索山 脈、伊朗高原北部的厄爾布爾士山脈到興都庫什山以及帕米爾高原的延伸山脈, 這些山脈區隔了北方的遊 牧帶與南方的定居帶。希臘化王國的建立使得亞洲地理範圍從小亞細亞進一步擴展至中亞、印度河流域。 西元前 138 年至西元後 166 年, 漢王朝先後與希臘化王國、羅馬帝國進行接觸, 從歐洲到東亞的地理空間才 真正聯結成為“絲綢之路”。

羅馬帝國時期的克勞狄烏斯 - 托勒密 (Claudius Ptolemaeus) 的地理學說進一步拓展了對亞洲地理空間 的認識,在 15 世紀末繪製的托勒密地圖採用半球面投影的方式,將平面圖呈現在球面之上。托勒密地圖關 於亞洲地理的描繪總共分為十二幅圖,包括小亞細亞半島、兩河流域、伊朗高原、阿拉伯半島及波斯灣、印度 半島、中亞東部、中亞西部以及馬來半島等,這反映出歐洲地理大發現之前對東方世界的詳盡描繪。西元 2 世紀, 中國的形象在羅馬帝國學者的亞洲地理敘述之中逐漸顯現, 托勒密對亞洲範圍的地理認識擴展到天 山與昆侖山之間的塔里木河流域, 而其中所描述的東方不僅包括印度,還有被稱為“賽里斯” (Seres) 的中國, 而 Seres 的詞源就是 “絲”, 這可以說是古代對 “絲綢之路” 最早的描述。劉迎勝認為托勒密《地理志》中所描 繪的東方是賽里斯指的是東漢控制下的西域, 托勒密所說的奧紮基亞山 (Auzakia) 為天山山脈的西段, 而卡 西亞山 (Kasia) 為昆侖山脈的西段, 兩山之間的奧伊哈爾德斯河 (Oikhardes) 為塔里木河 ${ }^{12}$ 。這可以與東漢時 期的廣義西域的“絲綢之路”地理觀形成鮮明對照。

第 2 , 中世紀歐洲所繪製的世界地圖以及呈現出的亞洲地理觀念受到基督教的影響, 並且凸顯了亞洲在 世界圖景中的核心地位, 也反映出古代西方 “絲綢之路” 地理觀所繿含的宗教與文明衝突張力。中世紀世界 地圖將耶路撒冷作為世界的中心, 而亞洲同時也是伊甸園所在的地方, 亞洲在此類地圖上的位置是在上方, 歐洲及非洲分別在下方的半圓之中, 這提示我們一一中世紀的世界地理觀念蘊含著一種以近東的亞洲作為 世界中心的傾向。例如中世紀的 T-O 地圖作為歐洲歷史上最早的印刷地圖, 它簡明而形象地勾勒出歐洲、 非洲與亞洲的相對位置, 在地圖的圓形結構中比較突顯的是上半圓的亞洲部分, 下半圓左右兩端分別相應 於歐洲與非洲, 而 “ $T$ ”形表示的是以地中海、頓河以及尼羅河作為三大洲之間的分界線, 亞洲、非洲及歐洲部 分分別標示著諾亞三個兒子——閃 (Shem)、含 (Ham) 以及雅弗 (Japheth) 的名字。他們各自分有不同的領 土, 並且被視為人類的祖先。義大利著名歷史學家維柯 (Giovanni Battista Vico) 認為其中閃族到達了中亞並 轉向東方, 雅弗族則到達北亞, 含族到達南亞、埃及和非洲, 他們背棄其父親諾亞的真教, 而成為世界各異教 民族的祖先。由此可見中世紀的地理觀念中, 亞洲與歐洲、非洲實際上作為《聖經》創世系統下整體大陸的 不同部分而存在,但同時亞洲的大部分又是異教民族的生存空間。

亞洲地理觀的拓展在歐洲地理學的演化中呈現出由西向東的外擴, 中世紀對亞洲的想像始終帶有異教 的投射, 十字軍漫長東征史正反映了歐洲對東方異教民族的抵抗與征服。然而, 13 世紀中葉所建立起來蒙 古帝國卻是由東方向西方的開拓, 遊牧民族打通了中國、伊斯蘭世界與西方之間的界限, 在陸路範圍上由中 亞深人到西亞, 東部邊界與歐洲、土耳其接壤, 並且開闢了由中國東南沿海到波斯以及義大利的海上航線, 這為歐亞地理空間的聯結提供了現實的土壤 ${ }^{13}$ 。羅馬教廷與亞洲腹地的蒙古帝國互派使者, 歐洲與亞洲兩 端形成地理空間視野的融合。而歐洲旅行家對於蒙古帝國統治下的阿拉伯、波斯、中亞、中國等亞洲各地的 考察, 也極大豐富了文藝復興時期歐洲人對亞洲地理的見聞與想像。例如居住在葡萄牙的猶太製圖學家亞 伯拉罕 - 科瑞斯科 (Abraham Cresques) 於 1375 年繪製完成的《加泰羅尼亞地圖集》以及亨利庫斯 - 馬特魯 斯 (Henricus Martellus) 於 1490 年發行的世界地圖, 都對《馬可 - 波羅遊記》中的亞洲地理知識有所採納和借

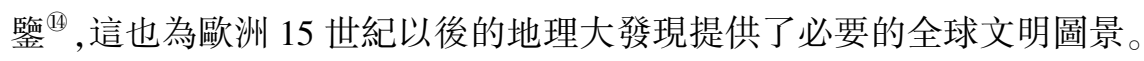

第三,15 世紀末西方開啟“地理大發現”, 歐洲地理觀念受此影響發生巨大變革, 由於開闢新航路的最初 意圖是探求通往東方的貿易之路,故而早期新航路在一定程度上可以看作是西方“絲綢之路” 的自然延伸。 哥倫布時代對世界的普遍認識還延續了中世紀時期三分法的陸地觀念——將世界看作是由亞洲、歐洲、非 
洲“三合一”所組成的大陸群, 因而哥倫布並不將新發現的大陸看作是獨立大陸,他一直誤以為美洲大陸即 夢䨽以求的亞洲。正如 E.G.R.泰勒所說, “哥倫布時代仍保留著的正統觀念是: [地球上] 只有一片單一有限 的,由三部分組成 (三合一) 的陸地,它被大洋包圍著,並被五個海互相交叉穿過。“陸地” ( continent 或 tierra firma) 這個字過去曾用於那些組成這塊陸地群的國家。……現代的“大陸’或“洲’ (Continent) 則指一大塊獨 立分開的陸地, 它是從新地理發現的實質被認識後才開始使用的字。哥倫布這個篤信宗教的人至死仍相信 他發現的地方是那塊三合一的陸地上尚不清楚的邊緣部分” ${ }^{15}$ 。由此可見,探求通往東方或亞洲的海上貿易 航路構成了歐洲地理大發現的動因,海洋既是大陸之間的天然阻隔, 又是洲際之間的主要通道, 因而 “海圖” 更強調世界圖景的海洋屬性, 並且側重於對海岸線的描摹以及海岸地名的標記, 這使得亞洲的海洋邊緣以 及外部輪廓在大航海時代得到鮮明的刻畫。大航海時代以後, 七大洲的地理輪廓也逐漸清晰化, 全球一體 或詈宇的地理圖景分化了中世紀的整體陸地的觀念, 亞洲也因此成為世界諸大陸中的一個獨立部分, 原有 僅限於歐亞之間的“絲絧之路”貿易也逐漸變成全球範圍內的洲際海陸貿易。

亞洲觀念在明末被引介到中國, 義大利人艾儒略 (Giulio Aleni) 來華傳教,並在 1625 年在中國學者的協 助下撰寫《職方外紀》, 其中描述了亞洲的地理範圍及其國家構成: “亞細亞者, 天下一大州也, 人類肇生之 地, 聖賢首出之鄉。其地西起那多理亞, 離福島六十二度; 東至亞尼俺峽, 離一百八十度; 南起爪哇, 在赤道 南十二度; 北至冰海, 在赤道北七十二度。所容國土不奠百餘。其大者首推中國, 此外曰韃而靼, 曰回回, 曰 印弟亞, 曰莫臥爾, 曰百兒西亞, 曰度兒格, 曰如德亞, 並此州巨邦也。” 所謂“福島”即大西洋的加那利群島, 在托勒密地圖中以此作為本初子午線的始點。“百兒西亞”、“度兒格”是明朝對“波斯”、“土耳其”兩國名稱 的音譯, 土耳其在當時是強盛時期的奧斯曼帝國, “如德亞” 是猶太人世居地。這種新的地理觀念將亞洲内 陸劃分為若干單元: 東部的中國、北方遊牧民、中亞回部、南亞印度 (莫臥兒王朝) 以及西亞的波斯、土耳其, 另外包括猶太人居住的迦南等地。晚清的魏源作《海國圖志》也正是按照這種地域觀, 將亞洲内陸劃分為西 域回部與五印度。早在 16 世紀初期,俄國尚未向東方拓展版圖, 而明朝的統治範圍未達到漠北地區, 廣闊亞 洲的內陸草原為遊牧民族韃靼所馳騁, 從中國的河西走廊一直到中亞的綠洲地帶則為穆斯林定居區。由於 遊牧民族曾經統治過中亞等伊斯蘭國家, 因而, 歐洲對亞洲內陸地理空間的認識存在“東鞋靼”與“西鞋靼” 的認識。

亞細亞的地理觀念觸動了明清之際士大夫的夷夏觀。明末時期徐光啟、方以智、徐應秋等學者留心於 西方天文學與舆地學, 也是最早引述亞洲地理觀念的中國人。明末㫿式穀認為如果按照《職方外貢》的《萬 國全圖》而論, 中國只是居亞洲十分之一, 而亞洲只佔有世界的五分之一, 倘若還是偏居一隅而視外邦為蠻 貃,那何異於井底之蛙,他進而指出夷夏的觀念不應局限於地域之別, “且夷夏何常之有? 其人而忠信焉, 明 哲焉, 元元本本焉, 雖遠在殊方, 諸夏也。若夫汶汶焉, 洰泪焉, 寡廉鮮恥焉, 雖近於比肩, 戎狄也。” “清初所 修《明史・外國傳七》在正史中最早介紹亞洲地理: “意大裏亞, 居大西洋中, 自古不通中國。萬歷時, 其國人 利瑪竇至京師, 為《萬國全圖》, 言天下有五大洲。第一曰亞細亞洲, 中凡百餘國, 而中國居其一。第二曰歐 羅巴洲, 中凡七十餘國, 而意大里亞居其一。第三曰利未亞洲, 亦百餘國。第四曰亞墨利加洲, 地更大, 以境 土相連, 分為南北二洲。最後得墨瓦臘泥加洲為第五。” 以上五大洲, 以亞洲為第一, 歐洲為第二, 顯然與 《職方外紀》排序有關,但也體現出一種由華夏文明漸次擴展出去的亞洲中心觀念。中國對歐洲的認知在明 以前主要體現在正史《西域傳》之中, 16 世紀末至 17 世紀初, 歐洲在科學方面尤其是實測領域的強盛讓明末 士人有所警醒,從而激發其對於西洋天文曆法及地理觀念的接受。清朝中期以前就已在西北地區運用西方 的測繪技術進行製圖,康熙皇帝聘請法國傳教士在中國內地大部分地區進行經緯度的測量,並繪製出了《皇 輿全覽圖》,這是用西方投影法繪製的第一幅中國地圖。清代對西域的地理測繪是在在乾隆時期開始的,隨 著對西北准噶爾部的平定先後對新疆地區及巴爾喀什湖以東及以南地區進行了較為全面的測量,設立了 90 多個經緯點,並最終形成了《乾隆內府舆圖》 ${ }^{19}$, 其中增不了西域、吐蕃新測繪資料,範圍包括了亞洲全圖, 體 現了亞洲地理觀對清代西域疆域測繪的影響。因此,作為古代西方“絲絧之路”的“亞細亞”地理觀念漸漸被 
清季以後的中國人所接受, 而與之相應的世界地理知識也在逐漸改變中國的天下觀念。

\section{三、近代“絲綢之路”的確立：“西域”與“亞細亞”的交匯}

晚清中國發生“三千年未有之大變局”, 這一變局可以從天下觀或世界觀的角度來理解。學者尤其注重 遼金元史傳統以及四裔之學, 從關注西北邊疆到邊疆以外的歐亞內陸,在研究視野上由域内轉向域外,他們 關注“西北”及“西域”也是近代中國學者“開眼看世界” 的最初契機, 當時學者將邊疆史地與域外史學相貫 通,而開啟對域外地理及世界地理的研究風氣。

而近代意義上 “絲綢之路”也隨著東西方的密切交流而最終確立, 學界一般認為德國地理學家李希霍芬 最早提出 “絲綢之路” ( Seidenstassen) 的地理名稱。近代以後的中國學者引介自俄國及歐洲的“俄屬中央亞 細亞”、“土耳其斯坦”、“突厥斯坦”、“亞洲高地” 等地理名稱, 大體相當於中國古代的廣義西域。而晚清學 者開始使用“中央亞細亞”等新的地理概念, 並且注意到這一區域在國際新秩序下的地緣特性。“中央亞細 亞” 被看作是一個獨立的地理空間及文化單元,並且被等同於古代的“西域”,同時也是近代西北史地學所關 注的領域。斯坦因稱西域為亞洲腹地 ( Innermost Asia), 也包含了内亞與西域相互嵌合的維度。自 20 世紀 20 年代開始, 學者又提出 “內陸亞洲” (Inner Asia) 這一概念, 其內涵與中央亞細亞較為類似, 海外新清史學 派以 “内陸亞洲” 的視角敘述清帝國的政治制度演變, 如果追溯新清史的論述方式, 其視角與晚清西北史地 學對西域的關注有內在聯繫, 歐文 - 拉鐵摩爾 (Owen Lattimore) 較早提出內亞概念, 其著作《中國的亞洲內陸 邊疆》( Inner Asian Frontiers of China) 論述以新疆、内蒙古、滿洲、西藏為代表的內陸邊疆的社會形態、歷史演 進, 將內陸與邊疆間的融合、互動作為一條主要線索。從廣義而論, 內亞的疆域範圍與古代絲絧之路相重 疊, 作為歐亞大陸的核心地帶, 也是東西方文明交流的彙聚地, 區域內民族特色鮮明、歷史演變複雜。從歷 史上來看, 內亞秩序的變革不僅僅影響本區域, 更有全球性的廣泛影響。實際上, 内亞的視角與晚清西北史 地學對西域的觀察視域非常接近, 也可以說在晚清學者那里就已經形成對絲絧之路與內陸邊疆的普遍關注。

追溯晚清學者對西域及內陸邊疆的關注, 自然與 19 世紀中後期的國際局勢有極大關係。隨著俄國、英 國等國在中亞及南亞的勢力擴張, 並且謀求佔領瓜分新疆地區, 西北邊疆危機日益加重, “西域”再度成為晚 清西北史地學所關注的重心。晚清學者宣揚塞防、邊務的邊疆治理方略以及清代開闢邊疆的“聖武”事蹟， 其意圖也在於扭轉晚清帝國在西北邊疆苃岩可危的統治, 恢復 “大一統” 的王朝盛世局面。但晚清所遭遇的 邊疆危機不同於歷朝歷代的邊患, 還需要放在國際秩序演變以民族國家建構的雙重背景下加以理解, 受此 影響, 清帝國的天下觀及西域觀為核心的地緣觀念漸趨瓦解。壟自珍提出 “西域置省” 的主張正在新國際形 勢之下提出的邊疆主權建構理念,也是傳統西域觀向近代亞洲觀的轉型與過渡。

正是在東西方文明激烈衝突的背景下, 晚清學者開始將廣義西域與亞洲内陸兩種圖景相互融合, 並且 重新審視晚清西北地區的地緣變革, 這種歷史觀與地理觀的雙重變革可以追溯至魏源的西北史地研究以及 對西方地理學的引介。魏源《海國圖志》之中描摹了兩種亞洲地圖: 其一是以《元經世大典圖》中元代疆域為 藍本, 繪製成《元代西北疆域沿革圖》; 其二是以近代西方經緯刻度的球面俯視圖為藍本, 稱為《亞細亞洲各 國圖》。第一種亞洲地圖的外部邊疆以東海、北海、南海、地中海等海洋為邊界, 其西域的範圍由新疆到歐洲 及非洲的邊緣, 但並沒有標示國界, 更加凸顯歐亞內陸空間的一體化; 第二種亞洲地圖呈現出現代世界地圖 的性質, 其中所顯示出的海洋並不僅僅有邊界的意義, 更主要的是具有了使各大洲交通互聯的作用, 有較為 清晰的國界與洲際分界。這兩種亞洲觀念在魏源那里並存, 這反映出清末西北史地學的兩種歷史敘述: 西 域史敘述是一種內陸型文明的表述, 而亞細亞敘述則是一種內陸與海洋並兼的全球文明的表述, 所謂“海 國” 的稱謂正是一種近代亞洲地理觀的體現。縱觀《海國圖志》全書, 魏源對亞洲地理方位以及歷史沿革的 梳理, 一方面引述《漢書》《後漢書》《魏書》《隋書》《唐書》等歷代西域傳, 另一方面輯錄了近代西方地理圖書 關於印度洋、印度及其相鄰大陸的記載。他把漢魏唐西域圖、元代西北疆域圖、亞細亞各國圖並列, 這些不 
同的地理知識的來源造成了魏源持有新舊兩種亞洲內陸觀。

由之可見, 在 19 世紀中後期隨著世界地理觀念的傳播, 當時的士人一方面繼續使用廣義西域來看待近 代的西亞地理空間, 另一方面又以近代的國際視野將西亞分為若干地理單元。清末學者認為此區域在古代 文明中佔據非常重要的地位, 為人類文明肇始之地, 而這正對應了近代意義上的 “絲綢之路” 文明圖景。晚 清西北史地學者多通過西域的視角考察歐亞國家間的地緣政治, 他們論述中國與俄國的地緣問題時, 既包 含一種古代西域地緣視角, 又引人近代西方的歐亞地緣視角, 從而形成了近代中國 “絲綢之路” 的地緣政治 視角。西北史地學者同時又是蒙元史研究者, 他們關注 13 世紀中期蒙古帝國對中亞的征服與統治, 這種統 治並不是隨著元朝的結束而瓦解, 其後的帖木兒帝國在中亞的統治一直延續至 16 世紀初, 而在帖木兒帝國 之後, 16 世紀中後期至 19 世紀中葉, 莫斯科大公國以及俄羅斯帝國的崛起加速了對西伯利亞及中亞地區的 擴展。何秋濤《朔方備乘》的焦點就是 19 世紀的 “俄國問題”, 這一問題與中國北部與西北部邊疆危機有直 接關係。他所繪製的“歷代北徼圖”正是關注歷代中國西北邊疆、西域以及烏拉爾山以東亞洲地緣的演變, 具有一種古今交匯的視角。在論述俄羅斯民族的歷史起源時, 何秋濤認為古代烏孫所處的地緣狀態與而近 代俄國非常類似, 他作《元代北徼諸王傳》, 考證元代時期西北藩國, 他注意到當時俄國全境都是在元代藩屬 封地之內, 並以西伯利亞在元朝時已列人中國版圖。因而, 何秋濤判定古代遊牧部族與近代民族國家之間 的關聯性, 不僅是基於人類學進行論證, 而且是有一種地緣政治的視野。從何秋濤的關注點, 可以看出晚清 西北史地學的視野擴展至小亞細亞半島的歐亞邊界, 這擴充了清代中期西北史地學的關注範圍, 實際上是 從世界地理的觀念來看待西北及西域, 而且他在 1853 年至 1858 年撰寫《朔方備乘》時留意到歐洲國家在 “土耳其”問題上的分歧。從中可見晚清學者探討西北邊疆與西域問題,實際已經具備一種觀察“絲綢之路” 沿線地帶的近代地緣政治觀。

因而,傳統的歷史敘述描述的是東西方帝國之間、遊牧政權與定居政權之間長達數千年的交往與融合， 而近代 “絲絧之路” 的文明圖景則顯示出對全球史觀與國際秩序的普遍關注。民國時期學者朱希祖認為西 域作為亞洲 “中樞” 的地位, 其地緣重要性不僅僅對於中國而言, 更是對歐亞大陸而言: “西域一地, 在吾國常 人視之, 以為邊疆, 無足輕重; 而以亞洲全局觀之, 實為中樞。蒙古統一亞洲, 先經營西域, 迨二區在握, 而後 西征弗庭, 前後左右, 鞭笞裕如, 其明證也。故欲統一亞洲者, 蒙古、西域, 首為兵事必爭之地, 歐亞強國, 荷 欲爭霸亞洲, 此二處必為最要之戰場; 然蒙古不過為甲乙二國最初決定勝負之區, 而欲控制全亞, 與其他各 國用兵, 必以西域為最要地矣。吾國新疆為西域最要區域, 吾國得之, 足以保障中原, 控制蒙古; 俄國得之, 可以東取中國, 南略印度; 英國得之, 可以囊括中亞細亞, 縱斷西伯利亞。” ${ }^{2}$ 因而, 近代中國西域觀向亞洲觀 的轉變也體現了天下圖景向全球圖景的轉換。

從“西域”到“亞細亞”不僅僅是東西方觀察視角的不同, 還體現了古今史觀的重大變革, 這種轉變背後 蓝含了全新的地理空間想像。“西域” 在《漢書》的原始語境中意味借著對外部世界的渴求與聯合, 但 “西 域” 作為一個參照視角始終在發生變化, 它既是對一種古代 “絲綢之路” 中各種文明體系的歷史敘述, 也體現 了在不同歷史階段中華夏文明與域外文明的聯繫與區分。而 “亞細亞” 作為西方對東方的想像, 它與歐洲、 非洲大陸既具有天然一體性, 又有一種宗教及文化上的特殊性, “亞細亞” 地理觀在明清之際傳人中國後成 與華夏世界觀相融合。近年來中國提出基於 “一帶一路” 架構的全球治理新思路, 其思想脈絡背後體現了一 種全球文明之間 “聯結”, 以消泯從中國西北內陸到中亞、西亞乃至歐洲、非洲各文明區域間的壁壘與隔閬, 這種經濟、貿易一體化思想實際上與古代的廣義西域視角有內在關聯性。

\section{注釋}

(1) 参見劉進寶《“絲絧之路”概念的形成及其在中國的傳播》,《中國社會科學》20 年第 11 期; 邬國義《“絲絧之路”名稱 概念傅播的歷史考察》, 《學術月刊》2019 年第 5 期; 劉再㮩《“絲綢之路”得名依據及“絲綢之路學”體系構建》, 《西北師大學 報》(社會科學版) 2020 年第 6 期; 袁劍《絲綢之路、地方知裁與區域秩序—“ “絲綢之路” 的概念、話語及其超越》, 《傸西師範 
大學學報》(哲學社會科學版) 2017 年第 4 期。

(2) 司馬悉:《史記》, 中華書局 1963 年版, 頁 3160 。

(3) 班固:《漢書》, 中華書局 1964 年版, 頁 3871 。

(4) 范靼: 《後漢書》卷七八《西域傅》, 中華書局 1965 年版, 頁 2910 。

(5) 余太山: 《古代地中海和中國關係史研究》, 商務印書館 2012 年版, 頁 45。

(6) 范靼:《後漢書》, 中華書局 1965 年版, 頁 2920 。

(7) 魏收:《魏書》, 中華書局 1974 年版, 頁 2261。

(8) 成一蕽:《從古地圖看中國古代的“西域”與“西域觀”》,《首都師範大學學報 (社會科學版)》2 018 年第 2 期, 頁 $25-32$ 。

(9) 郭華榕、徐天新主編:《歐洲的分與合》, 京華出版社 1999 年版, 頁 5 。

(10) [法]保羅・佩迪什:《古代希臘人的地理學: 古希臘地理學史》, 商務印書館 1983 年版, 頁 45 。

(11) 方豪: 《中西交通史》(上冊), 上海人民出版社 2008 年版, 頁 50 。

(12) 劉迎勝:《西北民族史與察合臺汗國史研究》, 南京大學出版社 1994 年版, 頁223-226。

(13) Biran, Michal. (2004). The Mongol transformation: From the steppe to Eurasian Empire. Medieval Encounters, pp. 339 -361 .

(14) 孫錦全:《東方文化西傅及其對近代歐洲的影響》,四川人民出版社 2012 年版, 頁 188 。

(15) E. G. R.泰勒:《哥倫布和世界地圖》, 載張至善編譯《哥倫布首航美洲: 歷史文獻與現代研究》, 商務印書館 1994 年 版, 頁 167 。

(16)艾儒略:《職方外紀》, 載李之藻編《天學初函》, 上海交通大學出版社 2013 年版, 頁 577 。

(17) 翟式穀:《職方外紀小言》, 載艾儒略著、謝方校釋《職方外紀校釋》, 中華書局 1996 年版, 頁 10 。

(18) 張廷玉等:《明史》, 中華書局 1974 年版, 頁 8459 。

(19)趙榮、楊正泰:《中國地理學史 (清代)》, 商務印書館 1998 年版, 頁 7 。

(20)曾問吾:《中國經營西域史》, 商務印書館 1936 年版, 頁 1 。 